IOS Press

\title{
Review
}

\section{Berries polyphenols: Nano-delivery systems to improve their potential in cancer therapy}

\author{
Tamara Y. Forbes-Hernández* \\ Department of Analytical and Food Chemistry, Nutrition and Food Science Group, CITACA, CACTI, \\ University of Vigo - Vigo Campus, Vigo, Spain
}

Received 6 February 2020; accepted 10 February 2020

\begin{abstract}
Berries bioactive compounds, specially polyphenols, have been widely recognized for their chemopreventive and chemotherapeutic properties. However, most of them struggle with chemical instability, low solubility, extensive metabolism and consequently poor bioavailability, which limit their clinical use. An effective strategy to overcome such problems consists of the nano-delivery systems. In the present review, the progress made in utilization of nano-carriers for berries polyphenols administration either alone or in combination with chemotherapeutic drugs have been summarized.
\end{abstract}

Keywords: Berries, bioactive compounds, polyphenols, cancer, nano-delivery systems, nanoparticles

$\begin{array}{ll}\text { Abbreviations } & \\ \text { CH-NPs } & \text { Chitosan-based nanoparticles } \\ \text { Cmax } & \text { Maximum plasma concentration } \\ \text { DL } & \text { Drug loading capacity } \\ \text { DMBA } & \text { 7,12-dimethylbenz[a]anthracene } \\ \text { DOX } & \text { Doxorubicin } \\ \text { EA } & \text { Ellagic acid } \\ \text { EE } & \text { Encapsulation efficiency } \\ \text { EGCG } & \text { Epigallocatechin-3-gallate } \\ \text { EPR } & \text { Enhanced permeability and retention effect } \\ \text { GOS } & \text { Galacto- oligosaccharide } \\ \text { GT } & \text { Gastrointestinal tract } \\ \text { HAS } & \text { Human serum albumin } \\ \text { HL-60/ADR } & \text { Doxorubicin resistant acute promyelocytic leukemia cell strain } \\ \text { HUVECs } & \text { Human umbilical vein endothelial cells } \\ \text { LC NPs } & \text { Liquid crystalline NPs } \\ \text { MCF-7/ADR } & \text { Doxorubicin resistant human breast carcinoma cell strain } \\ \text { MDA } & \text { Malondialdehyde }\end{array}$

\footnotetext{
*Corresponding author: Tamara Y. Forbes-Hernández, Department of Analytical and Food Chemistry, Nutrition and Food Science Group, CITACA, CACTI, University of Vigo - Vigo Campus, Vigo, Spain. E-mails: tamara.forbe@ gmail.com; tforbes@uvigo.es.
} 


$\begin{array}{ll}\text { MDR } & \text { Multidrug resistance } \\ \text { MMPs } & \text { Matrix metalloproteinases } \\ \text { MPEGPCL } & \text { Monomethoxy poly(ethylene glycol)- poly(3-caprolactone) } \\ \text { MPM } & \text { Mixed polymeric micelles } \\ \text { NLC } & \text { Nanostructured lipid carriers } \\ \text { NPs } & \text { Nanoparticles } \\ \text { PBA } & \text { Phenylboronic acid } \\ \text { PCL } & \text { Poly(c-caprolactone) } \\ \text { PEG } & \text { Polyethylene glycol } \\ \text { PEVs } & \text { Penetration enhancer-containing vesicles } \\ \text { PI } & \text { Polydispersity index } \\ \text { PLGA-PEG-COOH } & \text { PCL and poly(D,L-lactic-co-glycolic acid)- poly(ethylene glycol) conjugate } \\ \text { PMX } & \text { Pemetrexed } \\ \text { p-PDK1 } & \text { Phosphotidylinositol-dependent kinase-1 } \\ \text { QUE } & \text { Quercetin } \\ \text { QUE-ZnCPX } & \text { QUE-zinc complex } \\ \text { RGD } & \text { Arginyl-glycyl-aspartic acid } \\ \text { RGD-LPs } & \text { Arginyl-glycyl-aspartic acid- modified nano-liposomes } \\ \text { RGD-PEG } & \text { RGD- polyethylene glycol NPs } \\ \text { ROS } & \text { Reactive oxygen species } \\ \text { RVS } & \text { Resveratrol } \\ \text { SANP } & \text { Sodium alginate nanoparticles } \\ \text { TEM } & \text { Temozolomide } \\ \text { TMX } & \text { Tamoxifen } \\ \text { VCR } & \text { Vincristine } \\ \text { VEGF-1 } & \text { Vascular endothelial growth factor }\end{array}$

\section{Introduction}

Cancer is a major public health problem worldwide. According to the International Agency for Research on Cancer (IARC), the incidence of cancer in 2018 was estimated to be in 18.1 million new cases and 9.6 million cancer deaths around the world [1]. Treatments for the disease include radio- and chemo-therapy, surgery, and targeted immunotherapy [2]. However, current cytotoxic drugs present several limitations, including poor affordability and/or availability (especially in developing countries), and toxic effects on non-targeted tissues [2, 3]. Adverse side-effects of cytotoxic drugs include vomiting, stomatitis, alopecia, cardiomyopathy, leucopoenia, peripheral neuropathy and even secondary malignancy [3]. In addition, tumor cells may develop resistance to a wide variety of chemotherapeutic drugs or their combinations, which is known as multidrug resistance (MDR) $[3,4]$ and represents the main factor in the failure of many forms of chemotherapy regimens. MDR is caused by several mechanism such increased drug efflux, decreased drug uptake, evasion of drug-induced apoptosis, activation of DNA repair mechanisms or activation of detoxifying systems [5]. Hence, the urgent need for alternative treatments that can solve these problems.

In this regard, much attention is currently being paid to naturally occurring bioactive compounds, specially phytochemicals, which are plants secondary metabolites that can be found in seeds, fruits, vegetables, red wine, tea and olive oil $[2,6]$ and for which certain anticarcinogenic properties have been identified $[2,3,6,7]$. 
In this context, berries represent a valid alternative since they contain a lot of bioactive compounds, such as vitamins, minerals, and particularly, phenolic compounds including anthocyanins (pelargonidin, cyanidin, malvidin, peonidin, delphinidin), phenolic acids (caffeic, chlorogenisc, benzoic, coumaric and ferulic acids), flavonols (quercetin, and kaempferol), flavanols (catechins), hydrolysable tannins (ellagitannins and gallotannins), condensed tannins (proanthocyanidins) and stilbenes (resveratrol), among others [2]. Both, in vitro and in vivo studies have shown that berries polyphenols are able to inhibit tumor cell proliferation by cell cycle regulation and apoptosis induction, as well as to activate some signaling pathways including PI3K/AKT/PKB/mTOR, $\mathrm{NF}-\kappa \mathrm{B}, \mathrm{Wnt} / \beta$-catenin and ERK/MAPK. They also regulate major cell and tissue processes, as important as inflammation or angiogenesis $[2,8-10]$.

However, despite their potential chemopreventive and therapeutic activities, different pharmacokinetic, preclinical and clinical studies revealed significant shortcomings, such as non-specific tumor targeting [11], low bioavailability and consequent controversial efficacy $[2,7,11,12]$, which limit their application in therapeutics. For example, the estimated maximum plasma concentration $(\mathrm{Cmax})$ and the time required to reach this $\mathrm{Cmax}$ for anthocyanins is about $10^{-3} \mathrm{M}$ and $:<1-1.5 \mathrm{~h}$, respectively [7]. Low bioavailability has been related to poor absorption throughout the gastrointestinal tract (GT) (in their native form) and extensive metabolization by phase I/II detoxification enzymes and colonic microbiota, which lead to a wide range of new chemical structures before reaching their site of action $[2,7]$. In order to solve these problems and improve stability and/or bioavailability of berries phenolic compounds, nano-delivery systems have been proposed as effective tools that permit their effective transport in the tumor tissue [7, 11, 13, 14].

In this review the studies published in the last 10 years dealing with the topic of nanoparticles (NPs) utilization as a strategy to increase/improve berries polyphenols potential in cancer therapy have been summarized.

\section{Nano-delivery systems}

Application of nanotechnology in the treatment of cancer has gained remarkable attention in the recent years, since utilization of nano-carriers for bioactive molecules, or stabilized solid-drug NPs, may increase solubility, absorption and bioavailability of natural or synthetic bioactive compounds, protect them from premature degradation, and prolong their circulation time in the optimal dose. Additionally, nano-delivery systems improve intracellular penetration, reduce systemic toxicity of both, bioactive compounds and/or co-delivered drugs, and exhibit high differential uptake efficiency in target cells over normal cells [7, 15-18].

There is a wide variety of materials that can be used as nano-carriers, such as micelles, biodegradable polymers, drug-polymer polysaccharide conjugates, liposomes/vesicles, cubosomes, organometallic compounds, hydrogels and solid lipid NPs, among others [3, 14, 17-19]. Nano-delivery systems must be innocuous, stable, non-immunogenic, non-thrombogenic, non-inflammatory, and biodegradable [16, 19]. Among the most popular categories of nano-carriers stand out: i) nano-devices made up of biodegradable and biocompatible polymers, ii) liposomes and iii) solid lipid NPs.

\subsection{Polymeric-based NPs}

Polymeric NPs are particulate dispersions or solid particles with sizes ranging from 1 to $1000 \mathrm{~nm}$. According to their structural organization, they can be classified in nano-capsules (oily or aqueous cores surrounded by thin polymer membranes) or nano-spheres (a matrix-based organization of the polymeric chains) (Fig. 1) [20, 21]. Most of the time, they are coated with polyethylene glycol (PEG), which allows bioactive compounds to accumulate in tumors through the enhanced permeability and retention effect (EPR) [16]. Polymeric NPs may be obtained by polymer polymerization, coacervation, spontaneous emulsification, emulsion solvent evaporation, supercritical fluid technology and spray drying [21]. 

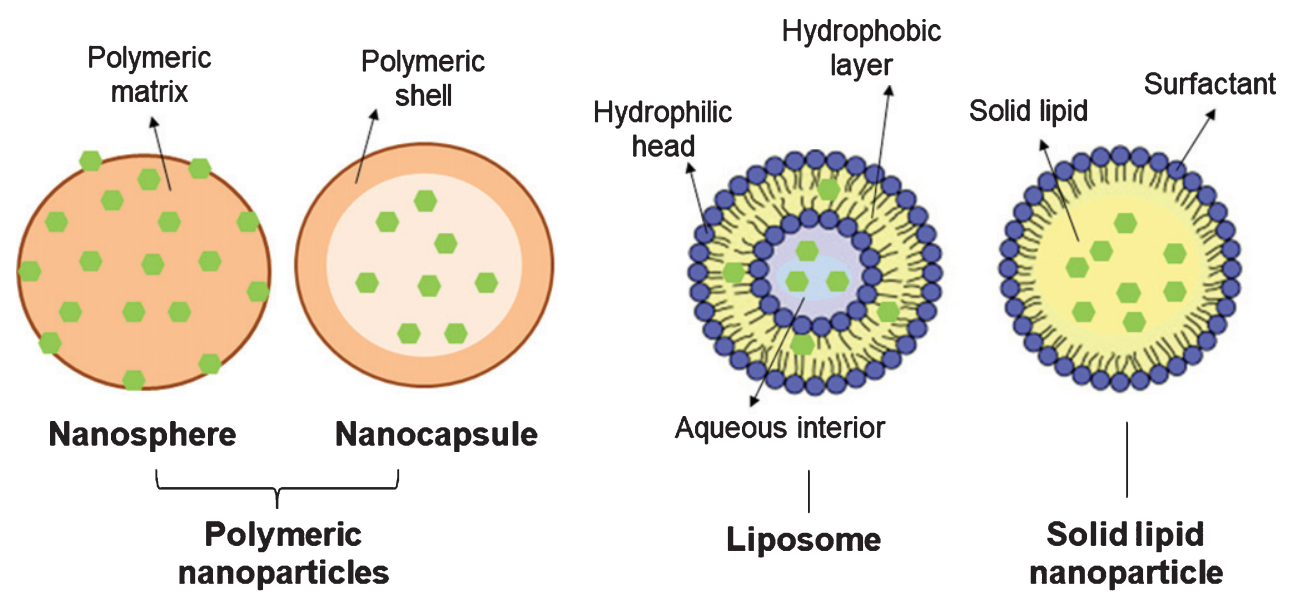

\section{Bioactive compound}

Fig. 1. Schematic representation of different nano-delivery systems.

\subsection{Liposomes}

Liposomes are spherical vesicles ( 20 to $1000 \mathrm{~nm}$ ) formed by one or more concentric lipid bilayers of amphipathic molecules and an inner aqueous compartment (Fig. 1) [21-24]. They offer several advantages, such as biocompatibility, controlled drug delivery and the possibility to immobilize or release both, hydrophilic and lipophilic compounds [18, 22]. Hydrophilic polyphenols (e.g. catechin) are dissolved in the aqueous cavity of liposomes, while lipophilic bioactives (e.g. quercetin and resveratrol) are trapped within the bilayer [23]. Numerous processes can be used to prepare liposomes, such as hydration of a thin lipid film followed by agitation, extrusion, sonication, high-pressure homogenization, or reverse-phase evaporation [21].

\subsection{Solid lipid NPs}

Solid lipid NPs are usually spherical and have an average size of 10 to $1000 \mathrm{~nm}$ (when dispersed in water). They possess a solid lipid core matrix -typically consisting of triglycerides, diglycerides, monoglycerides, fatty acids steroids, or waxes that can solubilize lipophilic molecules- which is stabilized by surfactants or emulsifiers (Fig. 1) [21, 25, 26]. They can be obtained by solvent evaporation, spray-drying, double emulsion, high pressure homogenization, ultra-sonication/high-shear technique, solvent emulsification-diffusion, supercritical fluid and ME-based methods.

Among the physicochemical characteristics of NPs, zeta potential, particle size and polydispersity index (PI) are crucial in determining nano-carriers colloidal stability, cellular or tissue uptake efficiency, biodistribution and cytotoxic effects [27-29]. Zeta potential has values that typically range from +100 to $-100 \mathrm{mV}$ and indicates the effective electric charge on the NPs surface, while PI denotes their size distribution. In general, NPs with zeta potential values greater than $+30 \mathrm{mV}$ or less than $-30 \mathrm{mV}$ show increased stability due to a larger electrostatic repulsion among particles [27]. Meanwhile, a particle size between 10 and $200 \mathrm{~nm}$ favors the extravasation, accumulation and slowly released of bioactive compounds at the specific tumor site through the enhanced EPR effect $[28,29]$, which is determined by the permeable vasculature and poor lymphatic drainage of the solid tumors. NPs larger than $10 \mathrm{~nm}$ are capable of leaking out from abnormal tumor micro-vasculature but unable to 
penetrate the gaps of normal blood vessels [3]. Thus, the dose of the drug or bioactive compound necessary to obtain a larger antitumor effect can be reduced [28].

The rigidity of nano-delivery systems also influences the cell entry mechanism. For example, rigid NPs are more susceptible to phagosomes formation, while soft nano-carriers uptake is mediated by micropinocytosis [29].

Other important aspects to consider when using NPs for the delivery of bioactive molecules are the Encapsulation Efficiency (EE), referred to the percentage of the bioactive molecule that is successfully entrapped into the nano-carrier, and the Drug loading capacity (DL), which indicates the percentage of the NP mass that is due to the encapsulated compound [3]. EE and Dl are usually calculated as follows [17, 30, 31]:

$$
\begin{gathered}
\mathrm{EE}=\frac{\text { Amount of drug encapsulated }}{\text { Amount of used drug }} \times 100 \\
\mathrm{DL}=\frac{\text { Amount of drug encapsulated }}{\text { Total nano-delivery system weight }} \times 100
\end{gathered}
$$

\section{Berries polyphenols nano-delivery systems}

\subsection{Flavonoids: Quercetin, epicatechin}

The cytotoxic effects of berries flavonoids NPs have been investigated in both in vitro and in vivo models. Most of the studies involved quercetin (QUE), either administered singularly or in combination with anti-cancer recognized drugs (co-delivery), while only few studies investigated the effects of other berries flavonoids such as epicatechin.

\subsubsection{Quercetin}

QUE is one of the most abundant dietary flavonols to which numerous biological activities have been attributed, including antioxidant, anti-inflammatory and chemo preventive properties [3, 17, 32]. It can inhibit cancer cells proliferation by inducing cell cycle arrest [3], intracellular reactive oxygen species (ROS) production [3] and apoptosis [3,17] through disruption of mitochondria, activation of caspases and release of cytochrome $\mathrm{c}$ [17]. It has also been reported that QUE may reduce matrix metalloproteinases (MMPs) secretion, leading to metastasis prevention [3].

However, therapeutic use of this flavonols is limited by its very low solubility in the upper GT [3, 15, 32-34], intestinal permeability [3] and high instability [3, 15]. In that sense, the recent use of nano-delivery systems has proven to be effective in increasing QUE bioavailability and efficacy. Table 1 summarizes the studies on anticancer effect of NPs containing QUE.

In MCF-7 [15, 33] and MDA-MB-231 [15] breast cancer cells, the use of biocompatible and biodegradable QUE-nanostructured lipid carriers (QUE-NLC) [15, 33] or mixed polymeric micelles containing QUE (QUE-MPM) [32] increased cytotoxicity and induced apoptosis in a dose-dependent manner. These effects were correlated not only to an augmentation of Bax protein expression along with a diminution of Bcl-2 expression, but also to a better QUE uptake by the tumor cells [33]. Both nano-delivery systems showed a sustained release pattern [15, 32], and augmented QUE solubility up to $~ 1000$ folds [15]. QUE-NLC also decreased the colony formation capacity and the antioxidant enzyme activity, while increased ROS levels and malondialdehyde (MDA) content in MCF-7 cells [33].

Similarly, QUE-MPM tested in the ovarian cancer cell lines SKOV-3 and NCI/ADR (epithelial and multi-drug resistant cells, respectively), caused a significant diminution of cell viability [32]. 
Table 1

Anticancer effects of nano-delivery systems containing berries polyphenols

\begin{tabular}{|c|c|c|c|c|c|c|}
\hline $\begin{array}{l}\text { Nanotechnology- } \\
\text { based system }\end{array}$ & Formulation & $\begin{array}{l}\text { Particle } \\
\text { size } \\
\text { (diameter) } \\
\end{array}$ & $\begin{array}{l}\text { Encapsulation } \\
\text { eficiency/Load } \\
\text { delivery } \\
\end{array}$ & $\begin{array}{l}\text { Experimental } \\
\text { Model }\end{array}$ & $\begin{array}{l}\text { Effects compared to the } \\
\text { treatment with the free- } \\
\text { bioactive compound }\end{array}$ & References \\
\hline \multicolumn{7}{|l|}{ Quercetin } \\
\hline Nanostructured lipid carriers & $\begin{array}{l}\text { Novel phase } \\
\text { inversion-based process } \\
\text { method }\end{array}$ & $32 \mathrm{~nm}$ & $\begin{array}{l}\text { EE: } 95 \% \\
\text { DL: } 11 \%\end{array}$ & $\begin{array}{l}\text { - MCF-7 and } \\
\text { MDA-MB-231 human } \\
\text { breast cancer cells }\end{array}$ & $\begin{array}{l}\text { - Decreased cell viability } \\
\text { - Induced apoptosis }\end{array}$ & {$[15]$} \\
\hline Solid lipid carriers & $\begin{array}{l}\text { Microemulsification } \\
\text { technique using } \\
\text { Compritol and Tween } 80\end{array}$ & $85.5 \mathrm{~nm}$ & EE: $97.6 \%$ & $\begin{array}{l}\text { - MCF-7 human breast } \\
\text { cancer cells }\end{array}$ & $\begin{array}{l}\text { - Reduced cell viability and } \\
\text { proliferation } \\
\text { - Increased apoptotic and } \\
\text { necrotic indexes }\end{array}$ & {$[33]$} \\
\hline Mixed polymeric micelles & $\begin{array}{l}\text { Thin film hydration } \\
\text { method }\end{array}$ & $25-45 \mathrm{~nm}$ & $\begin{array}{l}\text { EE: } 87-90.1 \% \\
\text { DL: } 8.75-9.01 \%\end{array}$ & $\begin{array}{l}\text { - MCF-7 and } \\
\text { MDA-MB-231 breast } \\
\text { cancer cells } \\
\text { - SKOV-3 and NCI/ADR } \\
\text { ovarian cancer cells } \\
\end{array}$ & - Decreased cells viability & {$[32]$} \\
\hline \multirow[t]{2}{*}{$\begin{array}{l}\text { Polymeric monomethyl } \\
\text { poly(ethylene } \\
\text { glycol)-poly(3-caprolactone) } \\
\text { micelles }\end{array}$} & $\begin{array}{l}\text { One-step solid dispersion } \\
\text { method }\end{array}$ & $\sim 31 \mathrm{~nm}$ & $\begin{array}{l}\text { EE: } 98.70 \% \\
\text { DL: } 14.8 \%\end{array}$ & $\begin{array}{l}\text { - } 4 \mathrm{~T} 1 \text { breast tumor cells } \\
\text { human } \\
\text { - HUVECs cells } \\
\text { Xenografts: }\end{array}$ & $\begin{array}{l}\text { - Induced apoptosis } \\
\text { - Inhibited proliferation, } \\
\text { migration and invasion }\end{array}$ & [13] \\
\hline & & & & $\begin{array}{l}\text { - mouse and } \\
\operatorname{Tg}(\text { FLK-1:EGFP }) \\
\text { zebrafish + 4T1 cells }\end{array}$ & $\begin{array}{l}\text { - Decreased tumor size and } \\
\text { number }\end{array}$ & [13] \\
\hline $\begin{array}{l}\text { Monomethoxy poly(ethylene } \\
\text { glycol)- poly( } 3 \text {-caprolactone) } \\
\text { micelles }\end{array}$ & Self-assembly & $36 \mathrm{~nm}$ & $\begin{array}{l}\text { EE: } 98.1 \% \\
\text { DL: } 6.9 \%\end{array}$ & $\begin{array}{l}\text { A2780S ovarian cancer } \\
\text { cells } \\
\text { Xenograft: } \\
\text { BALB/c nude } \\
\text { mice + A2780S cells }\end{array}$ & - Induced apoptosis & {$[17]$} \\
\hline RGD-modified nanoliposomes & $\begin{array}{l}\text { Thin film hydration } \\
\text { method }\end{array}$ & $93 \mathrm{~nm}$ & $\begin{array}{l}\text { EE: } 89 \% \\
\text { DL: } 9.3 \%\end{array}$ & $\begin{array}{l}\text { Xenograft: } \\
\text { C57BL/6 mice + A549 } \\
\text { lung cancer cells }\end{array}$ & - Inhibited tumor growth & {$[35]$} \\
\hline
\end{tabular}




\begin{tabular}{|c|c|c|c|c|c|c|}
\hline Chitosan nanoparticles & Ionic gelation method & $<200 \mathrm{~nm}$ & EE: $79.78 \%$ & $\begin{array}{l}\text { Xenograft: } \\
\text { C57BL6 mice + Human } \\
\text { lung cancer cell line A549 }\end{array}$ & $\begin{array}{l}\text {-Induced apoptosis and } \\
\text { reduced tumor size } \\
\text { - Enhanced tumor targeting }\end{array}$ & [3] \\
\hline Quercetin/zinc complex & $\begin{array}{l}\text { Metal ion-chelating } \\
\text { reaction }\end{array}$ & - & - & $\begin{array}{l}\text { BFTC-905 bladder cancer } \\
\text { cells }\end{array}$ & $\begin{array}{l}\text { - Inhibited migration and } \\
\text { invasiveness }\end{array}$ & [36] \\
\hline $\begin{array}{l}\text { Phenylboronic } \\
\text { acid/quercetin/zinc complex }\end{array}$ & $\begin{array}{l}\text { Conjugation of PBA and } \\
\mathrm{NH} 2-\mathrm{ZnO} \text { via amide bond } \\
\text { formation followed by } \\
\text { metal ion-ligand } \\
\text { coordination }\end{array}$ & $<40 \mathrm{~nm}$ & $\begin{array}{l}\text { EE: } 46.69 \% \\
\text { DL: } 29.83 \%\end{array}$ & $\begin{array}{l}\text { Xenograft: } \\
\text { EAC tumor bearing mice }\end{array}$ & - Reduced tumor growth & [11] \\
\hline $\begin{array}{l}\text { Sodium alginate nanoparticles } \\
\text { Chitosan nanoparticles }\end{array}$ & Co-axial electrospinning & $188 \mathrm{~nm}$ & $\begin{array}{l}\text { EE: } 92.2 \% \\
\text { DL: } 11.53 \%\end{array}$ & Caco- 2 cells & $\begin{array}{l}\text {-Retained antioxidant activity } \\
\text { - Inhibited cells proliferation } \\
\text { - Arrested cell cycle }\end{array}$ & [34] \\
\hline \multicolumn{7}{|l|}{ Epigallocatechin-3-gallate } \\
\hline $\begin{array}{l}\text { Penetration enhancer-containing } \\
\text { vesicles }\end{array}$ & Film hydration technique & $\sim 400 \mathrm{~nm}$ & EE: $83.4 \%$ & $\begin{array}{l}\text { - A431 epidermoid } \\
\text { carcinoma cells } \\
\text { Xenograft: } \\
\text { - DMBA-treated Balb/C } \\
\text { nude mice }\end{array}$ & $\begin{array}{l}\text { - Inhibited cell proliferation } \\
\text { - Reduced tumor size }\end{array}$ & [18] \\
\hline $\begin{array}{l}\text { Chitosan-based nanoparticles } \\
\text { (CH-NPs) }\end{array}$ & - & - & - & $\begin{array}{l}\text { - Human melanoma Mel } \\
928 \text { cells } \\
\text { Xenograft: } \\
\text { athymic (nu/nu) nude } \\
\text { mice + Mel } 928 \text { cells }\end{array}$ & $\begin{array}{l}\text { - Inhibited cell proliferation } \\
\text { - Induced apoptosis } \\
\text { - Induced cell cycle arrest } \\
\text { - Decreased tumor growth } \\
\text { - Induced apoptosis } \\
\text { - Induced cell cycle arrest }\end{array}$ & $\begin{array}{l}42] \\
{[42]}\end{array}$ \\
\hline $\begin{array}{l}\text { RGD-nanostructured lipid } \\
\text { carriers }\end{array}$ & $\begin{array}{l}\text { Hot homogenization } \\
\text { technique }\end{array}$ & $85 \mathrm{~nm}$ & $\begin{array}{l}\text { EE: } 83.03 \% \\
\text { DL: } 7.54 \%\end{array}$ & $\begin{array}{l}\text { - MDA-MB-231 human } \\
\text { breast cancer cells }\end{array}$ & $\begin{array}{l}\text { - Decreased cells } \\
\text { Proliferation } \\
\text { - Induced apoptosis } \\
\text { - Arrested cell cycle }\end{array}$ & [43] \\
\hline $\begin{array}{l}\text { Folic acid-polyethylene glycol } \\
\text { NPs }\end{array}$ & Ionotropic gelation & $142.7 \mathrm{~nm}$ & EE: $39.79 \%$ & $\begin{array}{l}\text { - MCF-7 human breast } \\
\text { cancer cells }\end{array}$ & $\begin{array}{l}\text { - Decreased cells proliferation } \\
\text { - Inhibited the PI3K-Akt } \\
\text { pathway }\end{array}$ & [40] \\
\hline
\end{tabular}


Table 1

(Continued)

\begin{tabular}{|c|c|c|c|c|c|c|}
\hline $\begin{array}{l}\text { Nanotechnology- } \\
\text { based system }\end{array}$ & Formulation & $\begin{array}{l}\text { Particle } \\
\text { size } \\
\text { (diameter) }\end{array}$ & $\begin{array}{l}\text { Encapsulation } \\
\text { eficiency/Load } \\
\text { delivery }\end{array}$ & $\begin{array}{l}\text { Experimental } \\
\text { Model }\end{array}$ & $\begin{array}{l}\text { Effects compared to the } \\
\text { treatment with the free- } \\
\text { bioactive compound }\end{array}$ & References \\
\hline \multicolumn{7}{|l|}{ Resveratrol } \\
\hline Liposomes & $\begin{array}{l}\text { Reverse-phase } \\
\text { evaporation method }\end{array}$ & $120 \mathrm{~nm}$ & EE: $95 \%$ & $\begin{array}{l}\text { - HeLa cells } \\
\text { - HepG2 cells }\end{array}$ & - Increased cytotoxicity & {$[30]$} \\
\hline Liposomes & $\begin{array}{l}\text { Reverse-phase } \\
\text { evaporation method }\end{array}$ & $\sim 100 \mathrm{~nm}$ & - & $\begin{array}{l}\text { - JIMT-1 cells } \\
\text { - MCF-7 human breast } \\
\text { cancer cells }\end{array}$ & - Increased cytotoxicity & [46] \\
\hline Liposomes & $\begin{array}{l}\text { Thin film hydration } \\
\text { method. }\end{array}$ & $131 \mathrm{~nm}$ & DL: $3.08 \%$ & - HT-29 colon cancer cells & - Increased cytotoxicity & [47] \\
\hline 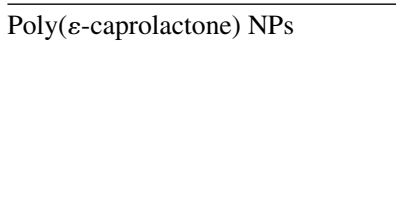 & Interfacial deposition & $<150 \mathrm{~nm}$ & - & $\begin{array}{l}\text { - B16F10 melanoma cells } \\
\text { Xenograft: } \\
\text { C57BL/6J mice + } \\
\text { B16F10 melanoma cells }\end{array}$ & $\begin{array}{l}\text { - Decreased cell viability } \\
\text { - Decreased tumor size } \\
\text { - Prevented pulmonary } \\
\text { hemorrhage and lung } \\
\text { metastasis }\end{array}$ & $\begin{array}{l}{[44]} \\
{[44]}\end{array}$ \\
\hline $\begin{array}{l}\text { Biocompatible blend of } \\
\text { poly(epsilon-caprolactone) and } \\
\text { poly(D,L-lactic-co-glycolic } \\
\text { acid)- poly(ethylene glycol) } \\
\text { conjugate NPs }\end{array}$ & Nanoprecipitation method & $150 \mathrm{~nm}$ & EE: 74-98\%, & $\begin{array}{l}\text { Postate cancer cell lines } \\
\text { DU-145, PC-3, and } \\
\text { LNCaP. }\end{array}$ & $\begin{array}{l}\text { - Decreased cell viability } \\
\text { - Increased cellular uptake }\end{array}$ & [49] \\
\hline Colloidal mesoporous silica NPs & - & $283 \mathrm{~nm}$ & $\begin{array}{l}\text { EE: } 100 \% \\
\text { DL: } 20 \%\end{array}$ & $\begin{array}{l}\text { HT-29 and LS147T colon } \\
\text { cancer cells } \\
\text { RAW264.7 macrophages }\end{array}$ & $\begin{array}{l}\text {-Decreased cell viability } \\
\text { - Suppressed LPS-induced } \\
\text { NF-kB activation }\end{array}$ & $\begin{array}{l}{[48]} \\
{[48]}\end{array}$ \\
\hline $\begin{array}{l}\text { Human serum albumin } \\
\text { (HSA)-RGD- polyethylene } \\
\text { glycol NPs (HAS-RGD-PEG NPs }\end{array}$ & $\begin{array}{l}\text { Traditional cross-linker } \\
\text { SPDP }\end{array}$ & $120 \mathrm{~nm}$ & EE: $62.5 \%$ & $\begin{array}{l}\text { PANC- } 1 \text { cells } \\
\text { Xenograft: } \\
\text { Balb/c nude mice + } \\
\text { PANC- } 1 \text { cells }\end{array}$ & $\begin{array}{l}\text {-Decreased cell viability - } \\
\text { Induced apoptosis } \\
\text { - Suppressed tumor growth } \\
\text { - Enhanced selective } \\
\text { accumulation in tumor tissues }\end{array}$ & {$[52]$} \\
\hline \multicolumn{7}{|l|}{ Ellagic acid } \\
\hline Chitosan NPs & Ionic gelation method & $176 \mathrm{~nm}$ & $\begin{array}{l}\text { EE: } 94 \% \\
\text { DL: } 33 \%\end{array}$ & $\begin{array}{l}\text { KB human oral cancer } \\
\text { cells }\end{array}$ & $\begin{array}{l}\text {-Reduced cell viability } \\
\text { - Induced DNA fragmentation }\end{array}$ & {$[31]$} \\
\hline 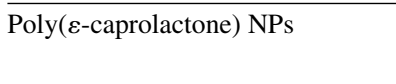 & $\begin{array}{l}\text { Emulsion-diffusion- } \\
\text { evaporation method }\end{array}$ & $193 \mathrm{~nm}$ & $\begin{array}{l}\text { EE: } 66.4-90.3 \% \\
\text { DL: } 56.8-78.6 \%\end{array}$ & HTC-116 cells & - Decreased cell viability & {$[54]$} \\
\hline
\end{tabular}


Biodegradable monomethoxy poly(ethylene glycol)- poly(3-caprolactone) (MPEGPCL) micelles have also been used to encapsulate QUE for treating A2780S ovarian cancer cells, established xenograft A2780S ovarian tumors [17], 4T1 breast tumor cells, human umbilical vein endothelial cells (HUVECs), Tg(FLK-1:EGFP) zebrafish and 4T1 tumor-bearing mice [13]. In all cases, QUE-MPEGPCL micelles showed higher cytotoxicity and better cellular uptake than free QUE. In A2780S cells and established xenograft A2780S ovarian tumors, QUE-MPEGPCL micelles inhibited cell proliferation and induced apoptosis by activating caspase-3 and -9 in a greater extent than non-encapsulated QUE. In addition, they upregulated Bax expression and mitochondrial transmembrane potential and downregulated Bcl-2 and MCL-1 [17]. On the other hand, QUE-MPEGPCL micelles significantly suppressed tumor growth and spontaneous metastasis of 4T1 breast carcinoma in both, transgenic zebrafish and mouse models. The number of tumor nodules and tumor size in the QUE micelle-treated groups were dramatically decreased in comparison with the control, empty NPs and free QUE groups. Furthermore, QUE-MPEGPCL micelles showed improved inhibitory capacity on embryonic angiogenesis and tumor-induced angiogenesis in the $\mathrm{Tg}$ (FLK-1:EGFP) zebrafish model compared with free QUE. They also prolonged the survival of tumor-bearing mice [13].

Arginyl-glycyl-aspartic acid (RGD) modified nano-liposomes (RGD-LPs) are other good carriers for QUE delivery in vivo. In mice bearing A549 lung tumors, RGD-LPs containing QUE significantly suppressed tumor growth without recurrence after 30 days of treatment. On the contrary, animals treated with free-QUE showed similar results to the control group, or even increased tumor volume. RGD-LPs were spherical, smooth and uniform in size, and suitable for intravenous administration [35]. Similar results were reported for quercetin loaded chitosan nanoparticles (QUE-CS NPs) [3]. In this case, treatment with QUE-CS NPs also triggered apoptosis and enhanced tumor specific targeting as demonstrated by the presence or not of fluorescence in lung, liver, heart and brain cryosection, respectively [3]. Authors attributed these effects to EPR effect and slow release of QUE inside the tumor cells.

In human BFTC-905 bladder cancer cells [36] and Subcutaneous Ehrlich Ascites Carcinoma (EAC) mice model, QUE-zinc complex (QUE-ZnCPX) or phenylboronic acid (PBA)-QUE-ZnCPX [11] also showed enhanced anti-cancer and anti-metastasis efficacies compared to free-QUE. QUE-ZnCPX markedly decreased BFTC-905 cells viability, motility and invasive capability in a dose- dependent manner through MT1-MMP and p-AKT down-regulation [36], while PBA- QUE-ZnCPX was able to reduce tumor growth in EAC bearing mice accompanied by lower associated toxicity in kidney, liver and spleen [11]. QUE release from the PBA- QUE-ZnCPX was $\mathrm{pH}$ sensitive; the amount released at $48 \mathrm{~h}$ was almost 47,28 and $13 \%$, at pH 5.0, 6.0 and 7.4, respectively [11]. Metal oxide NPs are a good choice among NPs for drug delivery, since they have tunable size and shape, surface chemistry and express wide range of oxidation states $[11,36]$.

In the particular case of colorectal cancer, some authors have proposed the use of colon-specific delivery system to increase QUE bioavailability and achieve maximal biological effects. The unique characteristics of the GT consent to design pH-, time-, or pressure- dependent nano-carriers as well as nano-delivery systems activated by microorganisms [34, 37]. In that sense, QUE-loaded sodium alginate nanoparticles (SANP) with a shell layer containing galacto-oligosaccharide (GOS) have been used to encapsulate, protect and release QUE at colon site. The obtained delivery system inhibited Caco-2 cells proliferation in a dose- and time-dependent manner by triggering apoptosis and arresting the cell cycle in the G0/G1 phase. The in vitro assays also revealed a sustained and specific release of QUE from the nano-carrier, which was enhanced by the presence of GOS. The polysaccharide-based NPs can be metabolized by colonic microbiota enzymes leading to the release of the encapsulated compounds. The antioxidant activity of QUE was also retained. In the same study, also chitosan was used as nano-carrier but its solubility in the gastric environment prevented the integrity of QUE-NPs to reach the colonic region [34].

QUE has also been used as a co-treatment together with traditional anti-cancer drugs taking advantage of the possibilities offered by nano-delivery systems. Combined therapies may improve efficacy and minimize acute side-effects associated with chemotherapy through synergic interactions, by counteracting ROS-mediated damage 
and by specifically targeting cancer cells, respectively [7]. Moreover, QUE is able to inhibit transmembrane protein P-gp, which is one the most important characteristic of MDR [4].

In MCF-7 [20] and 4T1 [19] breast cancer cell lines, QUE-loaded NPs for Tamoxifen (TMX) delivery significantly decreased cell viability in a concentration- and time-dependent manner compared to free-TMX, free-QUE or their combination. Likewise, multiple oral administration of TMX-QUE-NPs (TMX/QUE molar ratio 1:2 w/w) reduced tumor growth and residual tumor burden in DMBA (7,12-dimethylbenz[a]anthracene)-induced breast cancer in vivo model, while co-administration of free-TMX along with free-QUE had no effect. In addition, no mortality was verified in TMX-QUE-NPs-treated group in contrast with $\sim 50 \%$ deaths in animals treated with the free drugs and their combination. Co-loaded bioactive molecules also exhibited anti-angiogenic potential as revealed by normalized plasma levels of MMP-2 and MMP-9. Nevertheless, they could not avoid the hepatotoxicity caused by DMBA and free-TMX [20].

Also QUE co-encapsulated with vincristine (VCR) has been evaluated for anti-tumor efficacy in both in vitro and in vivo models of breast cancer [38] and Non-Hodgkin's lymphoma [28]. Liposome formulation containing VCR and QUE (molar ratio 2:1 w/w) showed strong cytotoxicity in the hormone- and trastuzumab-insensitive breast cancer JIMT-1 cells. Moreover, co-encapsulated drugs significantly inhibited tumor growth in the JIMT1 human breast tumor xenograft compared to free molecules or their combinations, without significant body weight loss in animals. The experimental group treated with the liposome co-encapsulated formulation showed tumor regression over 60-days, while in the animals treated with free- QUE, free- VCR or free- VCR/QUE combination, the tumors reached a volume of $500 \mathrm{~mm}^{3}$ after 30,36 and 50 days, respectively. Liposome delivery system extended plasma circulation of QUE and VRC without losing the synergistic drug ratio in vivo. The combination index value of the co-encapsulated formulation was 0.0900 , which means very synergistic activity or effect [38]. In human Burkitt's lymphoma cells and Raji cells bearing mice, VCR and QUE dual-loaded lipid-polymeric nano-carriers (VCR-QUE-LPNs) exhibited higher antitumor efficacy than VCR-QUE solutions. Co-encapsulated drugs inhibited tumor growth in a more efficient manner than drugs administered singularly or in combination. Bioactive molecules were sustainably released from the lipid-polymeric nano-carriers reaching 80-90\% cumulative drug release after 6 days. In addition, the distribution and accumulation of the VCR-QUELPNs was mainly in the tumor tissue in contrast to the non-encapsulated VCR-QUE solutions, which accumulated mostly in heart and kidney [28].

Yu et al., [4] demonstrated that QUE also improves the anti-tumor effects of doxorubicin (DOX) when co-administered within nano-carriers. DOX-QUE long-circulating liposomes (DOX-QUE-LP) significantly decreased cell viability in DOX-resistant human breast carcinoma cell strain (MCF-7/ADR) and DOX-resistant acute promyelocytic leukemia cell strain (HL-60/ADR), although no effects were observed in normal tumor cells (MCF-7 and HL-6). Likewise, in a tumor xenograft model (MCF-7/ADR cells bearing BALB/c nude mice), DOX-QUE-LP strongly inhibited the tumor growth in comparison with the free DOX and free DOX/QUE treated groups, as demonstrated by the diminution of the tumor volume up to 5.4 and 3.6 fold, respectively. The use of long-circulating liposomes reduced DOX distribution in normal tissues and the incidence of side effects and cardiotoxicity (the peak concentration of DOX in kidney, lung, heart and liver was significantly decreased), improving the safety and effectiveness of DOX use [4].

Finally, chitosan NPs loaded with 5-FU and QUE (molar ratio 2:1 w/w) exhibited significant toxicity to $\mathrm{MiaPaCa} 2$ pancreatic cancer cells both in 2D and 3D cultures [39]. Studies evaluating the anticancer effects of co-encapsulated QUE with chemotherapeutic drugs are summarized in Table 2.

\subsubsection{Epigallocatechin-3-gallate}

Although epigallocatechin-3-gallate (EGCG) is mainly found in green tea, it also occurs in some berries, including blackberries, cranberries, cherries and strawberries. Its biological activities comprise antioxidant capacity, skin protection against ionizing radiation-induced damage, enhancing weight loss [40], prevention of diabetes and neurodegenerative diseases [41] as well as cancer chemoprevention [40], among others. Both in vitro and 
Table 2

Anticancer effects of co-encapsulated berries polyphenols and chemotherapeutic drugs

\begin{tabular}{|c|c|c|c|c|c|}
\hline Drug & $\begin{array}{l}\text { Berries bioactive } \\
\text { compound }\end{array}$ & $\begin{array}{l}\text { Nano-delivery } \\
\text { system }\end{array}$ & Experimental model & Effects & References \\
\hline Tamoxifen & Quercetin & $\begin{array}{l}\text { Poly(lactic-co- } \\
\text { glycolic acid) } \\
\text { NPs }\end{array}$ & $\begin{array}{l}\text { - MCF-7 breast cancer cells } \\
\text {-DMBA-induced breast tumor } \\
\text { bearing female SD rats }\end{array}$ & $\begin{array}{l}\text { - Enhanced cytotoxicity - } \\
\text { - Higher tumor suppression } \\
\text { - Controlled tumor } \\
\text { angiogenesis }\end{array}$ & {$[20]$} \\
\hline Tamoxifen & Quercetin & $\begin{array}{l}\text { Polyester nano } \\
\text { sponge particles }\end{array}$ & - 4T1 mouse breast cancer cells & - Enhanced cytotoxicity & [19] \\
\hline Vincristine & Quercetin & Liposomes & $\begin{array}{l}\text { - JIMT-1 cells } \\
\text {-JIMT-1 cells bearing SCID mice }\end{array}$ & $\begin{array}{l}\text { - Enhanced cytotoxicity } \\
\text { Enhanced cytotoxicity - } \\
\text { Tumor regression }\end{array}$ & {$[38]$} \\
\hline Vincristine & Quercetin & $\begin{array}{l}\text { Lipid-polymeric } \\
\text { nano-carriers }\end{array}$ & $\begin{array}{l}\text { - Human Burkitt's lymphoma cells } \\
\text { - Raji cell bearing BALB/c mice }\end{array}$ & $\begin{array}{l}\text { - Enhanced cytotoxicity } \\
\text { - Higher tumor growth } \\
\text { inhibition }\end{array}$ & [28] \\
\hline Doxorubicin & Quercetin & $\begin{array}{l}\text { Long-Circulating } \\
\text { Liposomes }\end{array}$ & $\begin{array}{l}\text { - HL-60 and HL-60/ADR cells } \\
\text { - MCF-7 and MCF7/ADR cells } \\
\text { - MCF-7/ADR cells bearing BALB/c } \\
\text { nude mice }\end{array}$ & $\begin{array}{l}\text { - Enhanced cytotoxicity in } \\
\text { DOX resistant cells strain } \\
\text { - Decreased tumor volume }\end{array}$ & {$[4]$} \\
\hline Doxorubicin & $\begin{array}{l}\text { Epigallocatechin- } \\
\text { 3-gallate }\end{array}$ & $\begin{array}{l}\text { RGD-nanostructured } \\
\text { lipid carriers }\end{array}$ & $\begin{array}{l}\text { - MDA-MB-231 human breast cancer } \\
\text { cells }\end{array}$ & $\begin{array}{l}\text { - Increased apoptosis } \\
\text { - Inhibited cell cycle }\end{array}$ & [43] \\
\hline Doxorubicin & Resveratrol & Liposomes & $\begin{array}{l}\text { - Squamous cell carcinoma cell line } \\
\text { NT8 }\end{array}$ & $\begin{array}{l}\text { - Decreased cell viability } \\
\text { - Induced apoptosis } \\
\text { - Induced cell cycle arrest }\end{array}$ & [27] \\
\hline 5-Fluorouracil & Quercetin & Chitosan NPs & - MiaPaCa2 pancreatic cancer cells & - Enhanced cytotoxicity & [39] \\
\hline 5-FL & Resveratrol & Liposomes & $\begin{array}{l}\text { - SK-MEL-28 and Colo-38 } \\
\text { non-melanoma skin cancer cell lines }\end{array}$ & $\begin{array}{l}\text { - Decreased cell viability } \\
\text { - Induced apoptosis } \\
\text { - Induced cell cycle arrest }\end{array}$ & {$[50]$} \\
\hline Pemetrexed & Resveratrol & $\begin{array}{l}\text { Lyotropic liquid } \\
\text { crystalline NPs }\end{array}$ & $\begin{array}{l}\text { - Urethane-induced lung cancer } \\
\text { bearing Balb/c male mice }\end{array}$ & $\begin{array}{l}\text { - Decreased tumor weighty } \\
\text { - Decreased nephro- and } \\
\text { hepatotoxicit }\end{array}$ & {$[51]$} \\
\hline Temozolomide & Resveratrol & $\begin{array}{l}\text { Methoxy PEG -poly } \\
\text { epsilon caprolactone } \\
\text { NPs }\end{array}$ & $\begin{array}{l}\text { - U87 glioma cells } \\
\text { - U87 tumor-bearing nude mice }\end{array}$ & $\begin{array}{l}\text { - Increased apoptosis } \\
\text { - Decreased cell migration } \\
\text { - Decreased tumor growth }\end{array}$ & {$[53]$} \\
\hline
\end{tabular}

in vivo models have demonstrated that EGCG induced cell death in several types of cancers, such as breast, colon, kidney, brain and leukemia [40, 41]. However, it possesses low bioavailability, chemical instability and poor targeting ability, which limits its therapeutic use $[18,40]$. These disadvantages can be reversed using nanotechnology.

Chitosan-based NPs (CH-NPs) [42] and penetration enhancer-containing vesicles (PEVs) [15] have been successfully used to improve EGCG efficacy in both in vitro and in vivo models of skin cancer.

In human melanoma Mel 928 cells, EGCG-loaded CH-NPs significantly inhibited cell proliferation to a greater extent than native EGCG. Likewise, encapsulated EGCG was able to decrease tumor growth in a athymic $\mathrm{(nu} / \mathrm{nu})$ nude mice xenograft model: in native EGCG treated animals the tumor size was $820 \mathrm{~mm}^{3}$ while in the EGCG-loaded CH-NPs treated group was $650 \mathrm{~mm}^{3}$. Either in vitro or in vivo, EGCG-loaded CH-NPs induced 
apoptosis by increasing the $\mathrm{Bax} / \mathrm{Bcl}-2$ ratio and caspase 9 cleavage. They also induced cell cycle arrest in the G2/M phase through inhibition of cyclins D1/D3 and concomitant induction of p21 and p27 in a major extent than non-encapsulated EGCG [42].

On the other hand, EGCG-loaded PEVs inhibited cell proliferation on A431 epidermoid carcinoma cells and reduced tumor size in carcinogen (DMBA)-treated Balb/C nude mice. The effect of EGCG-loaded PEVs on the prevention and treatment of DMBA-induced skin tumors was significantly higher compared to EGCG aqueous solution. Tumor size in animals treated with EGCG-loaded PEVs during 3 weeks previous to DMBA exposition was $0.23 \mathrm{~mm}^{3}$ compared to $5 \mathrm{~mm}^{3}$ in the EGCG aqueous solution group. Likewise, when EGCGloaded PEVs were applied in DMBA-induced skin tumors the tumor size was reduced from $58.91 \mathrm{~mm}^{3}$ to 0.73 $\mathrm{mm}^{3}$ compared to a diminution from $58.91 \mathrm{~mm}^{3}$ to $3.79 \mathrm{~mm}^{3}$ in the EGCG aqueous treated animals. These effects were attributed to enhanced cellular uptake and accumulation of EGCG within tumor tissue by PEVs [18]. In addition, the histopathological examination of the mice skin revealed normal cellular architecture in the epidermis with normal thickening and no differentiation in the dermis in EGCG-loaded PEVs-treated animals, the multiple cutaneous lesions (ulcerative lesions) observed in the DMBA-treated animals. Similar effects were observed in EGCG aqueous solution-treated group, although the occurrence of epidermal hyperplasia was slightly higher. Furthermore, EGCG-loaded PEVs reverted the DMBA-induced oxidative stress damage in a major extent than EGCG aqueous solution as demonstrated by a higher antioxidant enzymes activities (superoxide dismutase and glutathione) and lower lipid peroxidation levels [18]. PEVs exhibited reasonable skin deposition and preserved the inherent antioxidant capacity of EGCG. In addition, \% EGCG degradation was significantly lower in EGCGloaded PEVs $(6.03 \%)$ compared to free-EGCG $(16.4 \%)$ after $24 \mathrm{~h}$ exposure to normal daylight, which is very favorable since one of the major limitations of EGCG topical use is its photosensitivity [18].

Utilization of folic acid-polyethylene glycol NPs (FA-PEG-NPs) [40] and RGD-nanostructured lipid carriers (RGD-NLC) [43] for EGCG encapsulation, also improved its anti-tumor effects on human breast cancer in vitro [40, 43]. In MCF-7 cells, EGCG-loaded FA-PEG-NPs inhibited cell proliferation in dose-dependent manner with an IC50 of $66.6 \pm 0.6 \mu \mathrm{g} / \mathrm{mL}$. The encapsulated EGCG noticeable decreased phosphotidylinositol-dependent kinase-1 (p-PDK1), p-Akt, Bcl-2 and CyclinD1 expression compared to non-treated cells and non-encapsulated EGCG group. Likewise, it up-regulated p21 and Bax expression, indicating that EGCG NPs inhibited MCF-7 cells proliferation by modulating the PI3K-Akt pathway [40]. On the other hand, EGCG-loaded RGD-NLC significantly increased cytotoxicity $(\mathrm{IC} 50=38.2 \mu \mathrm{M})$, apoptosis rate $(\sim 49 \%$ of cells) and cell cycle arresting in sub-G1in MDA-MB-231 cells, with more effectiveness than free EGCG. Encapsulating EGCG into RGD-NLC also resulted in more effective accumulation and targeting into tumor cells [43].

This latter nano-delivery system was also used for the co-encapsulation of the EGCG with DOX, showing that EGCG-loaded NLC-RGD increased the apoptotic effect and cell cycle arresting of DOX, due to the increased uptake by tumors and probably downregulation of P-glycoprotein (Table 2). Increasing the DOX effects may allow the use of lower concentrations of the drug which in turn would reduce the associated side effects [43].

Table 1 summarizes the studies on anticancer effect of NPs containing EGCG.

\subsection{Stilbenes: Resveratrol}

Resveratrol (3,4_,5-trihydroxy-trans-stilbene, RSV) is the most representative stilbene in the human diet and as far to our knowledge, the only one belonging to this group for which some papers dealing with the utilization of nano-delivery systems to increase the anti-cancer effects have been published. It can mainly be found in grapes barks and wine [30, 44].

Numerous biological properties have been attributed to RSV, including antioxidant, cardioprotective, antiinflammatory, antimicrobial, neuroprotective, immunomodulatory and anti-cancer effects [16, 29, 30, 44, 45]. However, its therapeutic applications are hindered by its low solubility [29, 30], extremely light sensitivity [16, 29, 44], low chemical stability [16], high rate of absorption and rapid clearance from the circulation [29, 44], which limits its bioavailability [16]. As for other phytochemicals, the use of nano-delivery systems has been 
demonstrated to be a valid strategy to overcome these limitations and increase its antitumor potential in many types of cancer, including breast [46], colon [47, 48], prostate [49], skin [44, 50] and lung [51] cancer.

The most commonly used nano-carriers for RVS encapsulation are liposomes and polymeric NPs. In comparison with free RVS, RVS-loaded liposomes significantly decreased cell viability in HeLa [30], HepG2 [30], trastuzumab-insensitive breast cancer JIMT-1 [46], MCF-7 [46] and HT-29 [47] cell lines. Lu et al., [30] attributed this effect to the increased concentration of RVS in aqueous solutions through the solubilization effect.

Poly( $\varepsilon$-caprolactone) (PCL) [44], biocompatible mixture of PCL and poly(D,L-lactic-co-glycolic acid)poly(ethylene glycol) conjugate (PLGA-PEG-COOH) [49], colloidal mesoporous silica [48] and human serum albumin (HSA)-RGD- polyethylene glycol NPs (HAS-RGD-PEG) [52] NPs have also been used to successfully encapsulate RVS. In murine B16F10 melanoma cells, PCL-NPs containing RVS significantly reduced cellular viability compared to non-encapsulated RVS. In the xenograft model (B16F10 melanoma-bearing mice), animals treated for 10 days with RVS-loaded PCL-NPs showed a significant reduction in the tumor size $\left(2807 \mathrm{~mm}^{3}\right)$ compared to free RSV treated animals $\left(7940 \mathrm{~mm}^{3}\right)$ and control group $\left(9656 \mathrm{~mm}^{3}\right)$. RVS nano-encapsulation also prevented pulmonary hemorrhage and metastasis, as evidenced by the lung histological analysis [44].

In another study, Sanna et al., [49] demonstrated that RVS-loaded PLGA-PEG-COOH significantly improved cytoxicity and cellular uptake in prostate cancer cell lines PC-3, DU-145, and LNCaP in a major extent than free RVS. The release of RVS from the NPs was sustained up to $12 \mathrm{~h}$ at $\mathrm{pH} 6.5$ and 7.4. This type of NP is usually absorbed by endocytosis and then released into intracellular locations, resulting in improved therapeutic action and reduced side effects.

Likewise, in colon cancer cell lines HT-29 and LS147T, the reduction of cell viability by RVS-loaded colloidal mesoporous silica NPs was significantly greater than the observed for non-encapsulated RVS. This effect was mediated by the Poly (ADP-Ribose) Polymerase (PARP-1) and cIAP1 pathways. In addition, encapsulated RVS suppressed lipopolysaccharide (LPS)-induced NF-kB activation in RAW264.7 macrophages. Encapsulation improved RVS solubility and release rate by 2.36 and 2.07 times with respect to the SVR alone, respectively [48].

Finally, encapsulated RVS in HAS-RGD-PEG NPs were highly effective in both in vitro and in vivo pancreatic tumor models. In PANC-1 cells, they were more cytotoxic and increased apoptosis to a greater extent than free RVS in a concentration dependent manner. The nano-delivery system improved RVS stability, release ratio $\left(58.4 .2 \pm 2.8 \%\right.$ at $\mathrm{pH} 5.0$ and $\left.37^{\circ} \mathrm{C}\right)$ and in vitro biocompatibility, which is favorable for biomedical applications. In tumor bearing mice, the content of HAS-RGD-PEG NPs in tumor tissue was 8.1-fold higher than that of free RV (selective accumulation), resulting in a better tumor suppression and less systemic toxicity over 35 days treatment [52]. Table 1 summarizes the studies on anticancer effect of NPs containing RVS.

Nano-encapsulation systems have also been successfully for co-treatment strategies using RVS and chemotherapeutic drugs (Table 2). On A549 lung cancer cells, co-delivery of RVS and pemetrexed (PMX), by using lyotropic liquid crystalline NPs (LC NPs), resulted in a higher cytotoxic effects (IC50=5.50 $\mu \mathrm{g} / \mathrm{mL}$ ) compared to non-encapsulated RSV/PMX mixture (IC50 $=7.96 \mu \mathrm{g} / \mathrm{mL}$ ), after $24 \mathrm{~h}$ of treatment. This effect was attributed to a better internalization of the nano-carriers. PMX-RVS-LC NPs also inhibited the tumor growth in urethane-induced lung cancer bearing mice through stimulation of apoptosis and angiogenesis inhibition, as evidenced by vascular endothelial growth factor (VEGF-1) diminution (1.49 fold vs RSV/PMX mixture) and caspase-3 escalation (1.47 fold vs RSV/PMX mixture), respectively. Average tumor weight in PMX-RSVLCNPs-treated animals ( $260 \pm 15 \mathrm{mg}$ ) was significantly lower compared to animals treated with free PMX/RSV mixture $(380 \pm 10 \mathrm{mg})$ and control group $(605 \pm 25 \mathrm{mg})$. Furthermore, PMX-RVS-LC NPs showed less nephroand hepatotoxicity, as well as a better survival rate (2 fold vs RSV/PMX mixture) [51].

The combination of RVS with temozolomide (TEM) (the main chemotherapeutic drug for malignant glioma) was also very effective when encapsulated into methoxy PEG -poly epsilon caprolactone (mPEG-PCL) NPs. In U87 glioma cells, TEM/RVS-encapsulated mPEG-PCL NPs showed higher apoptosis rate (60\%) as compared to free TEM/RVS (40\%). These effects were correlated to p-Akt inhibition which resulted in upregulation of caspase 3 and $\mathrm{Bcl}-2 / \mathrm{Bax}$ ratio diminution. The combination of encapsulated drugs also inhibited U87 cells migration in a 
major extent than free TEM/RVS. In the in vivo xenograft model, co-encapsulated TEM/RVS showed a stronger tumor growth inhibition compared to free TEM/RVS and control group, without any significant weight loss [53].

Liposomes have also been used for co-encapsulation of RVS with DOX [27] and 5-FL [50]. Their anti-tumor activities have been evaluated on squamous cell carcinoma cell line NT8 and non-melanoma skin cancer cell lines SK-MEL-28 and Colo-38, respectively. In all cases, co-encapsulated drugs in liposomal formulations showed better efficacy than the free combinations via apoptosis induction and cell cycle arrest $[27,50]$.

\subsection{Phenolic acids: Ellagic acid}

Ellagic acid (3,7,8-tetrahydroxy [1]- benzopyrano[5,4,3-cde] [1] benzopyran-5,10-dione, EA) is a polyphenol derived from hydrolysable ellagitannins. It can be found in several berries, such as strawberries, raspberries, blueberries and pomegranates. Numerous biological activities have been recognized for EA including antiinflammatory, radical scavenging capacity, anti-mutagenic and anti-carcinogenic properties [31, 45]. However, its low bioavailability and poor solubility limit its therapeutic use [31].

Also in this case, nanotechnology based-solutions have been proposed in order to solve these problems. In that sense, EA-loaded chitosan and poly ( $\varepsilon$-caprolactone) (PCL) NPs have been used as effective drug delivery for oral and colon cancer treatment, respectively. In KB human oral cancer cells, treatment with EA-chitosan NPs for $24 \mathrm{~h}$ significantly reduced cell viability and induced DNA fragmentation in a dose-dependent manner compared to non-encapsulated EA administration [31]. On the other hand, EA-loaded PCL NPs were able to decrease HCT-116 cells proliferation in a major extent than free EA, as demonstrated by the IC50 values of 0.11 and $13.2 \mu \mathrm{g} / \mathrm{mL}$, respectively. In addition, EA encapsulation resulted in an increased cellular uptake [54].

\section{Conclusions}

Nano-delivery systems improve chemopreventive and chemotherapeutic potential of berries polyphenols in both in vitro and in vivo models. They protect bioactive molecules from degradation in the GT while enhanced bioavailability, cellular uptake, retention time and specific delivery in the tumor site. Likewise, utilization of nano-carriers improves the cytotoxicity and reduced collateral damage of traditional chemotherapeutic drugs when co-encapsulated with natural occurring compounds.

\section{Acknowledgments}

Tamara Forbes Hernández is supported by a "Juan de la Cierva” post-doctoral contract.

\section{Funding}

The authors report no funding.

\section{Conflict of interest disclosure}

The Author has no any conflict of interest to disclose.

\section{References}

[1] Ferlay J, Colombet M, Soerjomataram I, Mathers C, Parkin DM, Piñeros M, et al. Estimating the global cancer incidence and mortality in 2018: GLOBOCAN sources and methods. Int J Cancer. 2019;144:1941-53.

[2] Afrin S, Giampieri F, Gasparrini M, Forbes-Hernandez T, Varela-López A, Quiles J, et al. Chemopreventive and therapeutic effects of edible berries: A focus on colon cancer prevention and treatment. Molecules. 2016;21:169. 
[3] Baksi R, Pratap Singh D, Borse SP, Rana R, Sharma V, Nivsarkar M. In vitro and in vivo anticancer efficacy potential of Quercetin loaded polymeric nanoparticles. Biomed Pharmacother. 2018;106:1513-26.

[4] Yu J, Chen H, Jiang L, Wang J, Dai J, Wang J. Codelivery of adriamycin and P-gp inhibitor quercetin using PEGylated liposomes to overcome cancer drug resistance. J Pharm Sci. 2019;108(5):1788-99.

[5] Gilet JP, Gottesman MM. Mechanisms of multidrug resistance in cancer. Methods Mol Biol. 2010;596:47-76.

[6] Goniotaki M, Hatziantoniou S, Dimas K, Wagner M, Demetzos C. Encapsulation of naturally occurring flavonoids into liposomes: Physicochemical properties and biological activity against human cancer cell lines. JPP. 2004;56:1217-24.

[7] Aiello P, Consalvi S, Poce G, Raguzzini A, Toti E, Palmery M, et al. Dietary flavonoids: Nano delivery and nanoparticles for cancer therapy. Semin Cancer Biol, 2019: https://doi.org/10.1016/j.semcancer.2019.08.029.

[8] Prasain J, Grubbs C, Barnes S. Cranberry anti-cancer compounds and their uptake and metabolism: An updated review. J Berry Res. 2019;1-10.

[9] Battino M, Forbes-Hernández TY, Gasparrini M, Afrin S, Cianciosi D, Zhang J, Manna PP, Reboredo-Rodríguez P, Varela Lopez A, Quiles JL, Mezzetti B, Bompadre S, Xiao J, Giampieri F. Relevance of functional foods in the Mediterranean diet: The role of olive oil, berries and honey in the prevention of cancer and cardiovascular diseases. Crit Rev Food Sci Nutr. 2019;59(6): 893-920.

[10] Peiffer DS. Preparing black raspberry components for their use as cancer therapeutics. J Berry Res. 2018;8(4):297-306.

[11] Sadhukhan P, Kundu M, Chatterjee S, Ghosh N, Manna P, Das J, Sil PC. Targeted delivery of quercetin via pH-responsive zinc oxide nanoparticles for breast cancer therapy. Mater SciEngCMater BiolAppl. 2019;100:129-40.

[12] Fang J. Bioavailability of anthocyanins. Drug Metab Rev. 2014;46(4):508-20.

[13] Wu Q, Deng S, Li L, Sun L, Yang X, Liu X, et al. Biodegradable polymeric micelle-encapsulated quercetin suppresses tumor growth and metastasis in both transgenic zebrafish and mouse models. Nanoscale. 2013;5:12480.

[14] Strugała P, Loi S, Bazanów B, Kuropka P, Kucharska AK, Włoch A, et al. A Comprehensive study on the biological activity of elderberry extract and cyanidin 3-O-Glucoside and their interactions with membranes and human serum albumin. Molecules. 2018;23:2566.

[15] Sun M, Nie S, Pan X, Zhang R, Fan Z, Wang S. Quercetin-nanostructured lipid carriers: Characteristics andanti-breast cancer activities in vitro. Colloids Surf B Biointerfaces. 2014;113:15-24.

[16] Siddiqui IA, Sanna V, Ahmad N, Sechi M, Mukhtar H. Resveratrol nanoformulation for cancer prevention and therapy. Ann N.Y. Acad Sci. 2015;1348:20-31.

[17] Gao X, Wang B, Wei X, Men K, Zheng F, Zhou Y, et al. Anticancer effect and mechanism of polymer micelle-encapsulated quercetin on ovarian cancer. Nanoscale. 2012;4:7021.

[18] El-Kayal M, Nasr M, Elkheshen S, Mortada N. Colloidal (-)-epigallocatechin-3-gallate vesicular systems for prevention and treatment of skin cancer: A comprehensive experimental study with preclinical investigation. Eur J Pharm Sci. 2019;137:104972.

[19] Lockhart JN, Stevens DM, Beezer DB, Kravitz A, Harth E. Dual drug delivery of tamoxifen and quercetin: Regulated metabolism for anticancer treatment with nanosponges. J Control Release. 2015;751-7.

[20] Jain AK, Thanki K, Jain S. Co-encapsulation of tamoxifen and quercetin in polymeric nanoparticles: Implications on oral bioavailability, antitumor efficacy, and drug-induced toxicity. Mol Pharmaceutics. 2013:10;3459-74.

[21] Fonseca-Santos B, DaflonGremião MP, Chorilli M. Nanotechnology-based drug delivery systems for the treatment of Alzheimer's disease. Int J Nanomedicine. 2015;10;4981-5003.

[22] Munin A, Edwards-Lévy F. Encapsulation of natural polyphenolic compounds: A Review. Pharmaceutics. 2011;3:793-829.

[23] Zhao D, Simon JE, Wu Q. A critical review on grape polyphenols for neuroprotection: Strategies to enhance bioefficacy. Crit Rev Food Sci Nutr. 2020;60(4):597-625.

[24] Squillaro T, Cimini A, Peluso G, Giordano A, Melone MAB. Nano-delivery systems for encapsulation of dietary polyphenols: An experimental approach for neurodegenerative diseases and brain tumors. Biochem Pharmacol. 2018;154;303-17.

[25] Ye JH, Augustin MA. Nano- and micro-particles for delivery of catechins: Physical and biological performance. Crit Rev Food Sci Nutr. 2019;59(10):1563-79.

[26] Pimentel-Moral Sl, Teixeira MC, Fernandes AR, Arráez-Román D, Martínez-Férez A, Segura-Carretero AEB. SoutoLipidnanocarriers for the loading of polyphenols - A comprehensive review. Adv Colloid Interface Sci. 2018;260:85-94.

[27] Mohan A, Narayanan S, Balasubramanian G, Sethuraman S, Krishnan UM. Dual drug loaded nanoliposomal chemotherapy: A promising strategy for treatment of head and neck squamous cell carcinoma. Eur J Pharm Biopharm. 2016;99:73-83.

[28] Zhu B, Yu L, Yue Q. Co-delivery of vincristine and quercetin by nanocarriers for lymphoma combination chemotherapy. Biomed Pharmacother. 2017;91:287-94.

[29] Abdel-Bar HM, Abd el Basset Sanad R. Endocytic pathways of optimized resveratrol cubosomes capturing into human hepatoma cells. Biomed Pharmacother. 2017;93:561-9. 
[30] Lu XY, Hu S, Jin Y, Qiu LY. Application of liposome encapsulation technique to improve anti-carcinoma effect of resveratrol. Drug Dev Ind Pharm. 2012;38(3):314-22.

[31] Arulmozhi V, Pandian K, Mirunalini S. Ellagic acid encapsulated chitosan nanoparticles for drug delivery system in human oral cancer cell line (KB). Colloids and Surfaces B: Biointerfaces. 2013;110:313-20.

[32] Patra A, Satpathy S, Shenoy AK, Abush J, Kazi M, Delwar Hussain M. Formulation and evaluation of mixed polymeric micelles of quercetin for treatment of breast, ovarian, and multidrug resistant cancers International. Int J Nanomedicine. 2018;13:2869-81.

[33] Niazvand F, Orazizadeh M, Khorsandi L, Abbaspour M, Mansouri E, Khodadadi A. E_ects of Quercetin-loaded nanoparticles on MCF-7 human breast cancer cells. Medicina. 2019;55:114.

[34] Wen P, Hu TG, Li L, Zong MH, Wu H. A colon-specific delivery system for quercetin withenhanced cancer prevention based on co-axial electrospinning. Food Funct. 2018;9:5999.

[35] Zhou X, Liu HY, Zhao H, Want T. RGD-modified nanoliposomes containing quercetin for lung cancer targeted treatment. Onco Targets Ther. 2018:11;5397-405.

[36] Lee YH, Tuyet PT. Synthesis and biological evaluation of quercetin-zinc (II) complex for anti-cancer and anti-metastasis of human bladder cancer cells. In Vitro Cell Dev Biol-Animal. 2019;55:395-404.

[37] Wen P, Zong M, Hu T, Li L, Wu H. Preparation and characterization of electrospun colon-specific delivery system for quercetin and its anti-proliferative effect on cancer cells. J Agric Food Chem. 2018;66(44):11550-9.

[38] Wong MY, Chiu G. Liposome formulation of co-encapsulated vincristine and quercetin enhanced antitumor activity in a trastuzumabinsensitive breast tumor xenograft model. Nanomedicine. 2011;7:834-40.

[39] Infanta DK, RaghavJaidev L, Sethuraman S, Maheswari Krishnan U. Dual drug loaded chitosan nanoparticles—sugar-coated arsenalagainst pancreatic cancer. Colloids and Surfaces B: Biointerfaces. 2015;135:689-98.

[40] Zeng L, Yan J, Luo L, Ma M, Zhu H. Preparation and characterization of (-)-Epigallocatechin-3-gallate (EGCG)-loaded nanoparticles and their inhibitory effects on Human breast cancer MCF-7 cells. Scientific Reports. 2017;7:45521.

[41] Wang D, Taylor EW, Wang Y, Wan X, Zhang J. Encapsulated nanoepigallocatechin-3-gallate and elemental selenium nanoparticles as paradigms for nanochemoprevention. Int J Nanomedicine. 2012;7:1711-21.

[42] Siddiqui IA, Bharali DJ, Nihal M, Adhami VM, Khan N, Chamcheu JC, et al. Excellent anti-proliferative and pro-apoptotic effects of (-)-epigallocatechin-3-gallate encapsulated in chitosan nanoparticles on human melanoma cell growth both in vitro and in vivo. Nanomedice. 2014;10(8):1619-26.

[43] Hajipour H, Hamishehkar H, NazariSoltan Ahmad S, Barghi S, Maroufi NF, Taheri RA. Improved anticancer effects of epigallocatechin gallate using RGD-containing nanostructured lipid carriers. Artific Cell NanomedBiotechnol. 2018;46(1).

[44] Carletto B, Berton J, Nascimento Ferreira T, FaccoDalmolin L, Paludo KS, Mainardes RM, et al. Resveratrol-loaded nanocapsules inhibit murine melanoma tumorgrowth. Colloids and Surfaces B: Biointerfaces. 2016;144:65-72.

[45] Forbes-Hernández T, Giampieri F, Gasparrini M, Mazzoni L, Quiles JL, Alvarez-Suarez JM, et al. The effects of bioactive compounds from plant foods on mitochondrial function: A focus on apoptotic mechanisms. Food ChemToxicol. 2014;68:154-82.

[46] Catania A, Barrajón-Catalán E, Nicolosi S, Cicirata F, Micol V. Immunoliposome encapsulation increases cytotoxic activity and selectivity of curcumin and resveratrol against HER2 overexpressing human breast cancer cells. Breast Cancer Res Treat. 2013;141: $55-65$.

[47] Soo E, Thakur S, Qu Z, Jambhrunkar S, Parekh HS, Popat A. Enhancing delivery and cytotoxicity of resveratrol through a dual nanoencapsulation approach. J Colloid Interface Sci. 2016;462:368-74.

[48] Summerlin N, Qu Z, Pujara N, Sheng Y, Jambhrunkar S, McGuckin M, et al. Colloidal mesoporous silica nanoparticles enhance the biologicalactivity of resveratrol. Colloids and Surfaces B: Biointerfaces. 2016;144:1-7.

[49] Sanna V, Siddiqui IA, Sechi M, Mukhtar H. Resveratrol-Loaded Nanoparticles Based on Poly(epsiloncaprolactone) and Poly(D,Llactic-co-glycolic acid)-Poly(ethyleneglycol) Blend for Prostate Cancer Treatment. Mol Pharm. 2013;10(10):3871-81.

[50] Cosco D, Paolino D, Maiuolo J, Di Marzio L, Carafa M, Ventura CA, et al. Ultradeformable liposomes as multidrug carrier of resveratrol and 5-fluorouracil for their topical delivery. Int J Pharm X. 2015;489:1-10.

[51] Abdelaziz HM, O Elzoghby A, Helmy MW, Samaha MW, Fang JY, Sfreag M. Liquid crystalline assembly for potential combinatorial chemo-herbal drug delivery to lung cancer cells. Int J Nanomedicine. 2019;14:499-517.

[52] Geng T, Zhao X, Ma M, Zhu G, Yin L. Resveratrol-loaded albumin nanoparticles with prolonged blood circulation and improved biocompatibility for highly effective targeted pancreatic tumor therapy. Nanoscale Res Lett. 2017;12:437.

[53] Xu H, Jia F2, Singh PK, Ruan S, Zhang H, Li X. Synergistic anti-glioma effect of a coloaded nano-drug delivery system. Int J Nanomedicine. 2017;12:29-40.

[54] Mady FM, Shaker MA. Enhanced anticancer activity and oral bioavailability of ellagic acid through encapsulation in biodegradable polymeric nanoparticles. Int J Nanomedicine. 2017;12:7405-17. 